\title{
Determining The Natural Radiation Level And Gamma Absorption Coefficient Of İkizdere Obsidian
}

\section{Selcen UZUN DURAN ( $\nabla$ selcenduran@ktu.edu.tr)}

Karadeniz Technical University: Karadeniz Teknik Universitesi

\section{Belgin Küçükömeroğlu}

Karadeniz Teknik Universitesi

Ali Çiriş

Niğde Üniversitesi: Nigde Omer Halisdemir Universitesi

Hakan Ersoy

Karadeniz Teknik Üniversitesi: Karadeniz Teknik Universitesi

\section{Research Article}

Keywords: Natural radioactivity, İkizdere Obsidian, Effective dose, elemental analyzes, mass attenuation coefficient

Posted Date: January 25th, 2022

DOI: https://doi.org/10.21203/rs.3.rs-912918/v1

License: () (1) This work is licensed under a Creative Commons Attribution 4.0 International License. Read Full License 


\section{Abstract}

In the present work, natural radionuclide levels and mass attenuation coefficient of obsidian samples taken from Rize íkizdere region were investigated. The mass attenuation coefficient $\left(\mu \rho^{-1}\right)$ is investigated experimentally and theoretically for 14 ikizdere obsidian rocks. The mass attenuation coefficients of the samples were measured experimentally at photon energies of radioisotopes ${ }^{133} \mathrm{Ba}(81 \mathrm{keV}, 302 \mathrm{keV}$, $356 \mathrm{keV}),{ }^{137} \mathrm{Cs}(662 \mathrm{keV})$, Theoretically, the simulation results of $\mu \rho^{-1}$ using XCOM code was compared with experimental results. In addition, elemental analyzes of obsidian samples were made. Average ${ }^{238} \mathrm{U},{ }^{232} \mathrm{Th}$ and ${ }^{40} \mathrm{~K}$ activities were determined as $93 \pm 9,67 \pm 7$, $1027 \pm 19 \mathrm{~Bq} \mathrm{~m}^{-3}$, respectively. The absorption coefficient of obsidian at 356 and $662 \mathrm{keV}$ energies is not much different from other rocks.

\section{Introduction}

Obsidian, a rock of volcanic origin, was formed as a result of the sudden cooling of the silicon-rich magma that emerged from the earth. Obsidian, also called volcanic glass; It can be found in black, brown, green and mixed translucent colors. It has a hardness of 5-6 according to the Mohs hardness scale and shows break in the form of a conchoidal fracture. Obsidian rock is nowadays; It is also used in the production of landscape architecture, furniture accessories, cosmetic products, and surgical scalpels and knives in medicine (Demir 2017). Turkey also black obsidian-Van and Ercis Artvin; green obsidian is mined around Nemrut Mountain-Tatvan, and red obsidian is mined around ikizdere-Rize. Intense iron minerals were found in the obsidian ore mined in Hasan Mountain. Gold minerals were found in the obsidian ore mined in ikizdere. Apart from that, in Turkey; Obsidian ores were also found in Kars, Mount Ararat and its vicinity and Pasinler. Therefore, Turkey is a very rich country in terms of obsidian ore reserves (Küçük and Gezer 2017).

Humans are constantly exposed to cosmic natural radiation from the sun and radioactive elements in varying proportions since the formation of the earth. In addition to these natural radiations, they are also exposed to radiation emitted from artificial radiation sources produced by humans. The dangers that radiation can cause are known to everyone. However, despite all these bad effects, it provides great benefits, especially in the treatment of cancer in medicine and in solving some biological problems. Since we cannot remove the radiation risk from our lives, we need to take protective measures to minimize the radiation hazard (Akkurt et al. 2011).

There are three basic ways to protect from radiation. These; distance, time and shielding. In these ways, shielding is the most important method of radiation protection. Shielding is based on placing material between the system to be protected and the radiation source. In addition to the experimental studies, the absorption coefficients can be calculated theoretically with the computer programs developed. A computer program XCOM was developed by the Berger and Hubbell which calculates attenuation coefficients and photon cross sections for elements compounds and mixtures in the energy range $1 \mathrm{keV}$ to $100 \mathrm{GeV}$ (Berger and Hubbell 1987). This widely used program transformed to windows platform called WinXCOM (Gerward et al. 2001). Using XCOM and WinXCOM, many attempts have been made to calculate attenuation coefficients for different elements, compounds and mixtures.

Studies have been conducted in the literature to determine the gamma ray absorption coefficients of many materials. Some of these are on the determination of the absorption coefficients of different elements, compounds and mixtures (Awasarmol et al. 2017a; Awasarmol et al. 2017b; Bhosale et al. 2016a; Bhosale et al. 2016b; Gaikwad et al. 2016; Pawar and Bichile 2013; Un and Sahin 2011). Among the studies carried out, there is also the study of the radiation absorption properties of many building materials (Akkurt et al. 2012; Akkurt et al. 2012; Medhat 2009). Various studies have been carried out to determine the absorption coefficients of various rocks (Obaid et al. 2018; Obaid et al. 2018; Nimet and Hatıpoglu 2018; Ozyurt et al. 2018; Cengız et al. 2019).

Studies on the absorption coefficient and radionuclide analysis of obsidian are limited in the literature (Chiozzi et al. 2000). In many studies on obsidian extracted in ikizdere, obsidians have been investigated in terms of mineralogical, petrographic, geochronological, geochemistry, as well as source studies with XRF analysis (Yeğingil et al.2002).In a different study, it was stated that obsidian contains a very small amount of crystalline phase and that this crystalline phase contains very little water (less than 1\%) (Ercan et al. 2016). In another study, it was revealed that obsidian rock found in the Rize (ikizdere) region can be used as a pozzolan material in cement (Ustabaş and Kaya 2018).

The aim of this study is to determine the natural radioactivity level of ikizdere Obsidian, to examine the gamma ray absorption properties and the effect of these rocks on radiation shielding. The gamma ray absorption coefficients of obsidians were calculated experimentally and theoretically (WinX-Com). Where the rocks were extracted, radionuclide measurements were made in order to examine the natural radiation concentration on site and to reveal the presence or absence of radioactivity. In addition, chemical element analyzes were carried out to determine the content of these rocks precisely. Thus, the radiological and chemical structure of these rocks mentioned above was determined. Various studies have been done on İkizdere obsidian, but no study has been done on radioisotope and absorption coefficients. 


\section{Material And Method}

\subsection{Study Area}

Figure 1 shows the regions where the samples were taken. The Eastern Pontides, one of Turkey's tectonic and geological associations, are divided into three separate regions, taking into account the structural and lithological features, defined as the Northern Zone, Southern Zones, and the Axial Zone (Arslan et al. 1997; Özsayar et al. 1981; Eyuboglu, Y. 2006). The study area is located in the Northern Zone. The oldest unit in the study area is late Cretaceous-aged Çağlayan Formation consisting of basalt, andesite, and pyroclastic rocks. The unit is observed southern and eastern parts of the study area and is overlain by late Cretaceous-Paleocene-aged Kaçkar Granitoid which presents vast outcrops surrounding the study area. Pliocene-Pleistocene aged trachyte-trachyandesite and obsidian outcrop in the middle and eastern sections of the area in relation with NE-SW and SE-NW trending faults.

\subsection{Preparation of Samples for Measurement}

Rock samples were taken within the scope of the field studies for the ikizdere district of Rize province, which is the study area. The samples taken from the surfaces of the obsidians with the help of a hammer were placed in clean, closable nylon bags and brought to the laboratory. The collected obsidian samples were broken and pounded with the help of crushers in the laboratory and passed through a 80 Mesh sieve for homogeneity. For chemical analysis, determination of mass absorption coefficients and radionuclide analysis, the samples must be ground and pulverized.

In order to form absorption discs, parts with a mass of approximately $1.5 \mathrm{~g}$ were taken from each sample and discs with a diameter of 12 $\mathrm{mm}$ were formed under 5 bar pressure with a hydraulic press machine. It was observed that the discs formed were strong and did not break down due to the structure of the samples.

For radionuclide analysis, crushed and pounded rock samples were placed in plastic boxes with a diameter of $6 \mathrm{~cm}$ and a height of $5 \mathrm{~cm}$, prepared in accordance with the experiment geometry, and the boxes were kept tightly closed for 1 month. Thus, the radioactive balance between ${ }^{238} \mathrm{U}$ and ${ }^{232} \mathrm{Th}$ products was achieved and the samples were made ready for counting.

\subsection{Experiment}

\subsubsection{Gamma Measurements}

Radionuclide analysis of obsidian samples that were ready for measurement was conducted with an high purity coaxial Ge detector (HPGe). HPGe detector (AMATEK-ORTEC-GEM25P4-76, U.S.A) with a relative efficiency of 33\%. The resolution of the system was $1.7 \mathrm{keV}$ at the $1332.5 \mathrm{keV}$ peak of ${ }^{60} \mathrm{Co}$. In the spectra, ${ }^{238} \mathrm{U}$ decay product ${ }^{214} \mathrm{~Pb}(295.2 \mathrm{keV}$ and $352 \mathrm{keV}),{ }^{214} \mathrm{Bi}(609.4 \mathrm{keV}),{ }^{232} \mathrm{Th}$ decay product ${ }^{212} \mathrm{~Pb}(238.6 \mathrm{keV}),{ }^{208} \mathrm{~T} 1$ (583.1), ${ }^{228} \mathrm{Ac}(911.1 \mathrm{keV}) ;{ }^{137} \mathrm{Cs}(661.6 \mathrm{keV})$ and ${ }^{40} \mathrm{~K}(1460 \mathrm{keV})$ peaks were determined and activity was calculated with the Equation-1 given below

$$
A=N /(m x \varepsilon x P x t)
$$

where $\mathrm{A}\left(\mathrm{Bq} \cdot \mathrm{kg}^{-1}\right)$ is the activity concentration of a radionuclide, $\mathrm{N}$ is the total net count of a specific gamma emissions, $\mathrm{m}$ is the mass of the sample $(\mathrm{kg}), \mathbb{}$ is the detector efficiency of the specific gamma emission, $\mathrm{P}$ is the absolute transition probability of that gamma emission, $t$ is the counting time. In water samples, unlike soil samples, the water sample volume was used instead of the sample mass. Spectral analysis was performed using the Genie 2000 software that was obtained from CANBERRA. After the activities of the water and soil samples were calculated, absorbed dose, annual effective dose and external hazard index were calculated. If a radionuclide activity is known then its exposure dose in air at $1 \mathrm{~m}$ above the ground can be calculated using the Equation-2 proposed by UNSCEAR 2000 (UNSCEAR, 2000).

$D(n G y / h)=\left(0.462 x A_{U}\right)+\left(0.604 x A_{T h}\right)+\left(0.0417 x A_{K}\right)$

$A_{U}, A_{T h}$ and $A_{K}$ are the activity concentrations of ${ }^{238} \mathrm{U},{ }^{232} \mathrm{Th}$ and ${ }^{40} \mathrm{~K}$, respectively, in the samples. The conversion factors of ${ }^{238} \mathrm{U},{ }^{232} \mathrm{Th}$ and ${ }^{40} \mathrm{~K}$ are $0.462,0.604$ and $0.0417 \mathrm{nGy} \mathrm{h}^{-1}$ per $\mathrm{Bq} \mathrm{kg}^{-1}$, respectively.

The Annual Effective Dose Equivalent was calculated from the Equation-3. 
In this equation; The Environmental Gamma Dose Conversion Factor does not change for both indoor and outdoor measurements and is taken as $0.7 \mathrm{~Sv} \mathrm{~Gy}^{-1}$. The occupation factor is the time people are exposed to these rays. In this study, occupation factor in Equation 4 was taken as 0.8 for indoor and 0.2 for indoor outside, considering that people spend $20 \%$ of their time outdoors and $80 \%$ indoors. Time is the number of hours in a year (8760 s/y) (UNSCEAR, 2000).

\subsubsection{Mass Absorption Coefficient Measurement}

It is necessary to measure with a gamma detector system to determine the gamma ray mass absorption coefficient of the samples created and the radionuclide concentrations in the samples. In this study, Amatek-Ortec-Gem25p4-76 model high purity coaxial Germanium detector (HPGe) was used. This device, which is used in the analysis of radioactive materials that emit gamma rays of different intensity and energy, consists of a radiation detector, liquid nitrogen-based cooling mechanism, electronic system and amplifiers that detect the generated signals. This detector has a resolution of $1.7 \mathrm{keV}$ at $1.33 \mathrm{MeV}$ and a relative efficiency of $33 \%$.

Each count was carried out for a period of 10.000 seconds, a total of 14 samples and three measurements were made for the blank count and calculations were made by taking the average of these three measurements. Gamma ray mass absorption calculations are made at four energy values. These are $80.99 \mathrm{keV}, 302.85 \mathrm{keV}, 356.01 \mathrm{keV}$ for ${ }^{133} \mathrm{Ba}$ and $661.66 \mathrm{keV}$, which is the only peak of ${ }^{137} \mathrm{Cs}$. Gamma ray mass absorption coefficients for obsidians were calculated by the following formulas.

If a material of thickness $\mathrm{x}$ is placed in the path of a beam of gamma radiations, the intensity of the beam will be attenuated according to Beer-Lambert's law:

$$
I=I_{o} e^{-\mu t}
$$

where $I_{0}$ and $I$ are the unnattenuated and attenuated photon intensities, respectively, and $\mu\left(\mathrm{cm}^{-1}\right)$ is the linear attenuation coefficient of the material.

A coefficient more accurately characterizing a given material is density-independent mass attenuation coefficients $\mu \rho^{-1}\left(\mathrm{~cm}^{2} \mathrm{~g}^{-1}\right)$ :

$$
I=I_{o} e^{\left(\frac{\mu}{\rho}\right) \rho x}=I_{o} e^{\left(\frac{\mu}{\rho}\right) d}
$$

Where " $\mathrm{d}$ " is the mass per unit area $\left(\mathrm{g} \mathrm{cm}^{-1}\right)$ and " $\mu \rho^{-1}$ " is the mass attenuation coefficient $\left(\mathrm{cm}^{2} \mathrm{~g}^{-1}\right)$ (Baltas 2020).

\section{3.3. Elemental Analysis}

Chemical analysis is carried out in order to determine the chemical content of the test samples and the amount of elements contained in it. In this study, X-ray fluorescence spectrometer (XRF), one of the chemical analysis methods, was used. The chemical contents of the test samples obtained after the grinding process were determined with the help of the XRF tester.

The samples were prepared as pellets without using any additives after drying at $10{ }^{\circ} \mathrm{C}$ for 1 day. The sample was placed in a $30 \mathrm{~mm}$ sample holder in accordance with the sample amount and semi-quantitatively studied in the form of oxide in the Boron-Uranium range. The results are prepared as both oxide and metal.

\section{Results}

\subsection{Elemental Analysis Results}

X-ray fluorescence spectrometer (XRF), one of the chemical analysis methods, was used to determine the amount of elements contained in the obsidian samples. Elemental analysis results of the rock samples as a result of the measurements are given in Table 1. 
Table 1

Chemical analysis results of obsidian samples.

\begin{tabular}{|c|c|c|c|c|c|c|c|c|c|c|c|c|c|c|}
\hline METAL & $1-A$ & 1-B & $1-C$ & $2-A$ & 3-A & 3-B & $3-C$ & 4-A & $5-A$ & 5-B & $5-C$ & 5-D & $6-A$ & 7-A \\
\hline 0 & 50.6 & 50.8 & 50.0 & 51.8 & 50.9 & 50.1 & 50.8 & 50.3 & 50.1 & 50.8 & 50.7 & 50.9 & 49.8 & 50.4 \\
\hline $\mathrm{Si}$ & 31.7 & 32.3 & 32.8 & 25.6 & 31.2 & 32.2 & 32.2 & 32.5 & 32.3 & 32.3 & 31.8 & 32.2 & 32.8 & 32.5 \\
\hline $\mathrm{Fe}$ & 0.940 & 0.944 & 1.06 & 0.711 & 1.02 & 0.982 & 1.02 & 1.02 & 1.13 & 0.932 & 1.15 & 0.994 & 1.01 & 1.06 \\
\hline $\mathrm{Al}$ & 7.31 & 7.44 & 7.43 & 5.96 & 7.60 & 7.37 & 7.45 & 7.66 & 7.40 & 7.37 & 7.19 & 7.40 & 7.48 & 7.53 \\
\hline $\mathrm{Mg}$ & 0.105 & 0.067 & 0.075 & 0.055 & 0.078 & 0.067 & 0.063 & 0.063 & 0.070 & 0.072 & 0.074 & 0.069 & 0.087 & 0.073 \\
\hline $\mathrm{Ca}$ & 0.725 & 0.728 & 0.738 & 0.539 & 0.715 & 0.705 & 0.726 & 0.754 & 0.834 & 0.745 & 0.871 & 0.723 & 0.780 & 0.791 \\
\hline C & 1.06 & - & - & 9.49 & 0.990 & 0.929 & - & - & - & - & - & - & - & \\
\hline $\mathrm{Ti}$ & 0.101 & 0.090 & 0.099 & 0.081 & 0.101 & 0.101 & 0.108 & 0.106 & 0.133 & 0.109 & 0.112 & 0.106 & 0.108 & 0.112 \\
\hline $\mathrm{Na}$ & 2.66 & 2.75 & 2.82 & 2.09 & 2.62 & 2.85 & 2.71 & 2.64 & 2.68 & 2.78 & 2.67 & 2.75 & 2.82 & 2.64 \\
\hline$P$ & 0.010 & - & 0.010 & 0.008 & 0.011 & 0.010 & 0.011 & - & - & 0.013 & 0.021 & - & - & 0.010 \\
\hline $\mathrm{Sr}$ & 0.019 & 0.019 & 0.019 & 0.014 & 0.020 & 0.018 & 0.020 & 0.020 & 0.024 & 0.019 & 0.023 & 0.020 & 0.022 & 0.021 \\
\hline$S$ & - & - & 0.005 & 0.008 & - & - & - & - & - & - & 0.019 & - & - & - \\
\hline $\mathrm{Cl}$ & 0.044 & 0.037 & 0.040 & 0.025 & 0.040 & 0.040 & 0.039 & 0.038 & 0.031 & 0.045 & 0.041 & 0.031 & 0.044 & 0.037 \\
\hline K & 4.52 & 4.63 & 4.72 & 3.53 & 4.56 & 4.47 & 4.71 & 4.80 & 5.19 & 4.64 & 5.10 & 4.65 & 4.91 & 4.73 \\
\hline $\mathrm{Cr}$ & - & 0.011 & 0.013 & 0.038 & - & - & - & - & - & 0.012 & - & - & - & 0.013 \\
\hline $\mathrm{Mn}$ & 0.062 & 0.060 & - & - & 0.056 & 0.048 & 0.048 & & 0.062 & 0.042 & 0.065 & 0.053 & - & 0.052 \\
\hline K & - & - & - & - & 4.56 & - & - & - & - & - & - & - & - & \\
\hline $\mathrm{Zr}$ & 0.015 & 0.015 & 0.018 & & 0.015 & 0.013 & 0.012 & 0.017 & 0.018 & 0.016 & 0.018 & 0.016 & 0.016 & 0.016 \\
\hline $\mathrm{Ni}$ & - & - & - & 0.012 & - & - & - & - & - & - & - & - & - & - \\
\hline $\mathrm{Ba}$ & 0.068 & 0.067 & 0.095 & - & 0.056 & 0.093 & 0.080 & 0.090 & 0.076 & 0.060 & 0.094 & 0.059 & 0.087 & 0.066 \\
\hline $\mathrm{Rb}$ & 0.016 & 0.016 & 0.017 & 0.013 & 0.017 & 0.016 & 0.017 & 0.018 & 0.021 & 0.016 & 0.020 & 0.017 & 0.019 & 0.017 \\
\hline OXIDE & $1-A$ & $1-B$ & $1-C$ & $2-A$ & $3-A$ & 3-B & $3-C$ & $4-A$ & $5-A$ & 5-B & $5-C$ & $5-D$ & $6-A$ & $7-A$ \\
\hline $\mathrm{SiO}_{2}$ & 69.6 & 72.5 & 72.5 & 49.7 & 69.0 & 70.0 & 72.3 & 72.1 & 71.7 & 72.5 & 71.7 & 72.4 & 72.3 & 72.2 \\
\hline $\mathrm{Al}_{2} \mathrm{O}_{3}$ & 14.1 & 14.6 & 14.4 & 10.4 & 14.7 & 14.1 & 14.6 & 14.9 & 14.4 & 14.5 & 14.1 & 14.5 & 14.5 & 14.7 \\
\hline $\mathrm{Fe}_{2} \mathrm{O}_{3}$ & 1.40 & 1.46 & 1.60 & 0.864 & 1.53 & 1.44 & 1.58 & 1.55 & 1.72 & 1.44 & 1.78 & 1.54 & 1.52 & 1.62 \\
\hline $\mathrm{MgO}$ & 0.176 & 0.114 & 0.126 & 0.084 & 0.132 & 0.112 & 0.108 & 0.107 & 0.12 & 0.124 & 0.128 & 0.118 & 0.147 & 0.125 \\
\hline $\mathrm{CaO}$ & 1.05 & 1.10 & 1.09 & 0.646 & 1.05 & 1.01 & 1.10 & 1.12 & 1.24 & 1.13 & 1.32 & 1.09 & 1.14 & 1.18 \\
\hline $\mathrm{CO}_{2}$ & 3.97 & - & - & 31.7 & 3.74 & 3.46 & - & - & - & - & - & - & - & - \\
\hline $\mathrm{TiO}_{2}$ & 0.176 & 0.163 & 0.174 & 0.115 & 0.178 & 0.173 & 0.194 & 0.188 & 0.24 & 0.196 & 0.203 & 0.192 & 0.19 & 0.198 \\
\hline $\mathrm{Na}_{2} \mathrm{O}$ & 3.64 & 3.81 & 3.88 & 2.64 & 3.60 & 3.87 & 3.76 & 3.64 & 3.69 & 3.85 & 3.70 & 3.82 & 3.87 & 3.63 \\
\hline $\mathrm{P}_{2} \mathrm{O}_{5}$ & 0.025 & 0.024 & 0.023 & 0.016 & 0.026 & 0.023 & 0.026 & 0.025 & 0.021 & 0.033 & 0.052 & 0.024 & - & 0.025 \\
\hline SrO & 0.023 & 0.024 & 0.024 & 0.014 & 0.024 & 0.022 & 0.025 & 0.025 & 0.030 & 0.025 & 0.030 & 0.025 & 0.027 & 0.026 \\
\hline $\mathrm{K}_{2} \mathrm{O}$ & 5.65 & 5.98 & 5.97 & 3.69 & 5.76 & 5.52 & 6.08 & 6.11 & 6.61 & 6.00 & 6.62 & 6.01 & 6.17 & 6.04 \\
\hline $\mathrm{Cr}_{2} \mathrm{O}_{3}$ & - & 0.018 & 0.020 & 0.048 & - & - & - & - & - & 0.019 & - & - & - & - \\
\hline
\end{tabular}




\begin{tabular}{|c|c|c|c|c|c|c|c|c|c|c|c|c|c|c|}
\hline METAL & $1-A$ & 1-B & $1-C$ & $2-A$ & 3-A & 3-B & $3-C$ & 4-A & $5-A$ & $5-B$ & $5-C$ & $5-D$ & 6-A & 7-A \\
\hline $\mathrm{ZrO}_{2}$ & 0.021 & 0.022 & 0.026 & - & 0.021 & 0.018 & 0.018 & 0.025 & 0.025 & 0.023 & 0.027 & 0.023 & 0.023 & 0.024 \\
\hline $\mathrm{MnO}$ & - & - & - & - & - & 0.063 & - & - & - & & 0.092 & 0.074 & & - \\
\hline $\mathrm{SO}_{3}$ & 0.083 & 0.084 & 0.012 & 0.018 & 0.077 & - & 0.067 & - & 0.085 & 0.023 & 0.052 & - & - & 0.072 \\
\hline $\mathrm{Cl}$ & - & - & 0.042 & 0.022 & - & 0.041 & - & 0.040 & - & 0.048 & 0.044 & 0.033 & - & 0.011 \\
\hline $\mathrm{BaO}$ & 0.045 & 0.040 & 0.112 & - & 0.042 & 0.106 & 0.042 & 0.107 & 0.033 & 0.073 & 0.113 & 0.071 & 0.046 & 0.039 \\
\hline $\mathrm{Rb}_{2} \mathrm{O}$ & 0.079 & 0.081 & 0.020 & 0.012 & 0.066 & 0.018 & 0.096 & 0.021 & 0.091 & 0.019 & 0.024 & 0.020 & 0.102 & 0.078 \\
\hline $\mathrm{NiO}$ & 0.019 & 0.020 & - & 0.012 & 0.019 & - & 0.020 & - & 0.025 & - & - & - & 0.022 & 0.021 \\
\hline
\end{tabular}

As can be seen, except for the 2-A coded obsidian sample, the others contain an average of $70 \% \mathrm{SiO}_{2}$. While the silicon ratios of the samples are approximately close to each other, it is seen that the other chemical contents differ.

\subsection{Radıonuclıd Results Of Obsıdıan Samples}

Radionuclide analysis of obsidian samples collected from 7 different areas from ikizdere Region was performed by gamma spectrometry method. While the ${ }^{137} \mathrm{Cs}$ activity in all of the samples is well below the limit values, the ${ }^{238} \mathrm{U}-{ }^{232} \mathrm{Th}^{-40} \mathrm{~K}$ values and the dose equivalents and annual effective dose values calculated by considering these values are given in Table 2.

Table 2

Gamma spectroscopic analysis of obsidian samples and annual effective dose values.

\begin{tabular}{|llllll|}
\hline Samples & ${ }^{238} \mathbf{U}$ & ${ }^{232} \mathrm{Th}$ & ${ }^{40} \mathrm{~K}$ & $\mathrm{D}$ & AEDE \\
\cline { 2 - 6 } & $\left(\mathrm{Bq} \mathrm{kg}^{-1}\right)$ & & & $\left(\mathrm{nGy} \mathrm{s}^{-1}\right)$ & $\left(\mu \mathrm{Sv}^{-1}\right)$ \\
\hline 1-A & $87 \pm 7$ & $63 \pm 6$ & $1085 \pm 24$ & 123.5 & 151.5 \\
\hline 1-B & $100 \pm 9$ & $73 \pm 7$ & $978 \pm 13$ & 131.08 & 160.8 \\
\hline 1-C & $95 \pm 8$ & $69 \pm 5$ & $910 \pm 16$ & 124 & 152.1 \\
\hline 2-A & $103 \pm 7$ & $71 \pm 9$ & $973 \pm 17$ & 131.2 & 161 \\
\hline 3-A & $79 \pm 6$ & $57 \pm 5$ & $1046 \pm 21$ & 114.5 & 140.4 \\
\hline 3-B & $121 \pm 11$ & $73 \pm 9$ & $1261 \pm 23$ & 153 & 188 \\
\hline 3-C & $72 \pm 7$ & $62 \pm 5$ & $988 \pm 22$ & 112 & 138 \\
\hline 4-A & $73 \pm 9$ & $59 \pm 5$ & $930 \pm 12$ & 108.4 & 133 \\
\hline 5-A & $106 \pm 10$ & $74 \pm 8$ & $1052 \pm 16$ & 138 & 170 \\
\hline 5-B & $89 \pm 9$ & $67 \pm 8$ & $1079 \pm 23$ & 127 & 156 \\
\hline 5-C & $82 \pm 7$ & $69 \pm 8$ & $1149 \pm 25$ & 128 & 157 \\
\hline 5-D & $134 \pm 13$ & $76 \pm 10$ & $998 \pm 14$ & 150 & 184 \\
\hline 6-A & $76 \pm 8$ & $61 \pm 6$ & $948 \pm 17$ & 111.5 & 137 \\
\hline 7-A & $87 \pm 9$ & $66 \pm 8$ & $981 \pm 19$ & 121 & 148.4 \\
\hline Mean & $93.14 \pm 9$ & $67.15 \pm 7$ & $1027 \pm 19$ & & 155.5 \\
\hline
\end{tabular}

\subsection{Mass Absorption Coefficient Results of Obsidian Samples}


The count peaks with $81,302,356,661 \mathrm{keV}$ energy in the gamma spectrum of each sample and the count peaks obtained without the sample in the detector were analyzed. These values are placed in Formula 4-5. Thus, mass absorption coefficients were obtained experimentally. Experimental and theoretical absorption coefficients obtained are given in Table 3.

Table 3

Mass absorption coefficients of samples for gamma ray at specified energies.

\begin{tabular}{|lllllllll|}
\hline Samples & 81 keV & \multicolumn{3}{c}{$302 \mathrm{keV}$} & \multicolumn{3}{c}{$356 \mathrm{keV}$} & \multicolumn{3}{l|}{ (61 keV } \\
\cline { 2 - 8 } & nist & exp & nist & exp & nist & exp & nist & exp \\
\hline 1-A & 0.203 & $0.210 \pm 0.0025$ & 0.107 & $0.108 \pm 0.0021$ & 0.100 & $0.102 \pm 0.0034$ & 0.077 & $0.074 \pm 0.0026$ \\
\hline 1-B & 0.205 & $0.207 \pm 0.0021$ & 0.1069 & $0.109 \pm 0.0024$ & 0.100 & $0.099 \pm 0.0023$ & 0.077 & $0.076 \pm 0.0027$ \\
\hline 1-C & 0.206 & $0.212 \pm 0.0021$ & 0.107 & $0.108 \pm 0.0030$ & 0.100 & $0.094 \pm 0.0027$ & 0.077 & $0.083 \pm 0.0032$ \\
\hline 2-A & 0.209 & $0.218 \pm 0.0018$ & 0.107 & $0.105 \pm 0.0032$ & 0.100 & $0.092 \pm 0.0032$ & 0.077 & $0.080 \pm 0.0034$ \\
\hline 3-A & 0.209 & $0.210 \pm 0.0016$ & 0.107 & $0.106 \pm 0.0019$ & 0.100 & $0.099 \pm 0.0033$ & 0.077 & $0.084 \pm 0.0029$ \\
\hline 3-B & 0.209 & $0.215 \pm 0.0019$ & 0.107 & $0.109 \pm 0.0015$ & 0.100 & $0.091 \pm 0.0024$ & 0.077 & $0.073 \pm 0.0041$ \\
\hline 3-C & 0.209 & $0.213 \pm 0.0017$ & 0.107 & $0.105 \pm 0.0023$ & 0.100 & $0.096 \pm 0.0019$ & 0.077 & $0.076 \pm 0.0034$ \\
\hline 4-A & 0.209 & $0.220 \pm 0.0023$ & 0.107 & $0.111 \pm 0.0032$ & 0.100 & $0.097 \pm 0.0021$ & 0.077 & $0.075 \pm 0.0037$ \\
\hline 5-A & 0.209 & $0.219 \pm 0.0034$ & 0.107 & $0.104 \pm 0.0026$ & 0.100 & $0.098 \pm 0.0023$ & 0.077 & $0.085 \pm 0.0052$ \\
\hline 5-B & 0.209 & $0.221 \pm 0.0026$ & 0.107 & $0.106 \pm 0.0029$ & 0.100 & $0.094 \pm 0.0031$ & 0.077 & $0.081 \pm 0.0050$ \\
\hline 5-C & 0.209 & $0.226 \pm 0.0029$ & 0.107 & $0.111 \pm 0.0040$ & 0.100 & $0.103 \pm 0.0034$ & 0.077 & $0.083 \pm 0.0031$ \\
\hline 5-D & 0.209 & $0.224 \pm 0.0030$ & 0.107 & $0.111 \pm 0.0021$ & 0.100 & $0.101 \pm 0.0028$ & 0.077 & $0.084 \pm 0.0040$ \\
\hline 6-A & 0.209 & $0.213 \pm 0.0024$ & 0.107 & $0.109 \pm 0.0023$ & 0.100 & $0.98 \pm 0.0035$ & 0.077 & $0.085 \pm 0.0034$ \\
\hline 7-A & 0.209 & $0.211 \pm 0.0027$ & 0.107 & $0.113 \pm 0.0027$ & 0.100 & $0.102 \pm 0.0029$ & 0.077 & $0.084 \pm 0.0037$ \\
\hline
\end{tabular}

\section{Discussion And Conclusion}

In this study, gamma ray absorption properties of ikizdere Obsidian and the effect of these rocks on radiation shielding were investigated. The absorption coefficients of obsidians were calculated experimentally and theoretically (WinX-Com). In addition, in the places where the rocks were extracted, radionuclide measurements were made in order to examine the natural radiation concentration on site and to reveal the presence or absence of radioactivity. In addition, chemical element analyzes were made to determine the content of these rocks precisely. Thus, the radiological and chemical structure of these rocks mentioned above was determined. Table 4 compares the studies on obsidian in the literature with the results of this study. In Table 5, the comparison of the absorption coefficients of various rock samples at $356 \mathrm{keV}$ and $662 \mathrm{keV}$ is given. 
Table 4

Comparison of ${ }^{238} \mathrm{U},{ }^{232} \mathrm{Th},{ }^{40} \mathrm{~K}$ levels of various obsidian samples.

\begin{tabular}{|c|c|c|c|c|}
\hline \multirow[t]{2}{*}{ Obsidian Samples } & ${ }^{238} \mathrm{U}$ & ${ }^{232} \mathrm{Th}$ & ${ }^{40} \mathrm{~K}$ & \multirow[t]{2}{*}{ References } \\
\hline & \multicolumn{3}{|l|}{$\left(\mathrm{Bq} \mathrm{kg}^{-1}\right)$} & \\
\hline 01 & $183 \pm 2$ & $219 \pm 0.004$ & $1379 \pm 17$ & \multirow[t]{3}{*}{ [22] } \\
\hline 02 & $167 \pm 2$ & $193 \pm 0.003$ & $1368 \pm 15$ & \\
\hline 03 & $175 \pm 2$ & $197 \pm 0.004$ & $1314 \pm 16$ & \\
\hline Black Obsidian & $81.2 \pm 15$ & $80.2 \pm 22$ & $1528 \pm 76$ & \multirow[t]{2}{*}{ [21] } \\
\hline Brown Obsidian & $73.5 \pm 16$ & $75.5 \pm 16$ & $1767 \pm 80$ & \\
\hline İkizdere Obsidian Mean & 93 & 67 & 1027 & This Study \\
\hline
\end{tabular}

Table 5

Comparison of the mass absorption coefficients of various rock samples at $356 \mathrm{keV}$ and $662 \mathrm{keV}$ gamma energy levels.

\begin{tabular}{|llll|}
\hline Rock Samples & $356 \mathrm{keV}$ & $662 \mathrm{keV}$ & References \\
\hline Feldspathic basalt & 0.101 & 0.078 & {$[17]$} \\
\hline Compact basalt & 0.098 & 0.078 & {$[17]$} \\
\hline Olivine Basalt & 0.0989 & 0.0759 & {$[18]$} \\
\hline Volcanic rock & 0.110 & 0.080 & {$[17]$} \\
\hline Dolerite & 0.099 & 0.077 & {$[17]$} \\
\hline 1-A & $0.102 \pm 0.0034$ & $0.074 \pm 0.0026$ & This Study \\
\hline 1-B & $0.099 \pm 0.0023$ & $0.076 \pm 0.0027$ & This Study \\
\hline 1-C & $0.094 \pm 0.0027$ & $0.083 \pm 0.0032$ & This Study \\
\hline 2-A & $0.092 \pm 0.0032$ & $0.080 \pm 0.0034$ & This Study \\
\hline 3-A & $0.099 \pm 0.0033$ & $0.084 \pm 0.0029$ & This Study \\
\hline 3-B & $0.091 \pm 0.0024$ & $0.073 \pm 0.0041$ & This Study \\
\hline 3-C & $0.096 \pm 0.0019$ & $0.076 \pm 0.0034$ & This Study \\
\hline 4-A & $0.097 \pm 0.0021$ & $0.075 \pm 0.0037$ & This Study \\
\hline 5-A & $0.098 \pm 0.0023$ & $0.085 \pm 0.0052$ & This Study \\
\hline 5-B & $0.094 \pm 0.0031$ & $0.081 \pm 0.0050$ & This Study \\
\hline 5-C & $0.103 \pm 0.0034$ & $0.083 \pm 0.0031$ & This Study \\
\hline 5-D & $0.101 \pm 0.0028$ & $0.084 \pm 0.0040$ & This Study \\
\hline 6-A & $0.98 \pm 0.0035$ & $0.085 \pm 0.0034$ & This Study \\
\hline 7-A & $0.102 \pm 0.0029$ & $0.084 \pm 0.0037$ & This Study \\
\hline
\end{tabular}

As seen in Table 4, the average ${ }^{238} \mathrm{U}$ level of İkizdere obsidian was found as $93,{ }^{232} \mathrm{Th}$ level as 67 , and ${ }^{40} \mathrm{~K}$ level as $1027 \mathrm{~Bq} \mathrm{~m}^{-3}$. These values are compared with other limited number of studies. It is seen that ${ }^{238} \mathrm{U}$ levels of obsidian samples are almost half less than 01-0203 samples, and ${ }^{232} \mathrm{Th}$ levels are less than one quarter. Radionuclide values of obsidian samples in this study, Turkey's Iğdır obsidian samples were compared with radionuclide values enacted in the region. Although the ${ }^{238} \mathrm{U}$ level of the ikizdere region obsidians is similar to the one extracted from the Iğdır Region, ${ }^{232} \mathrm{Th}$ and ${ }^{40} \mathrm{~K}$ levels are lower than those extracted from the Iğdır region. In Table 5 , the mass absorption coefficients of various rocks with similar energies are given. The absorption coefficient of obsidian at 356 and $662 \mathrm{keV}$ energies is not much different from other rocks. 


\section{References}

1. Demir M (2017) Sarıkamış Obsidiyen Kaynakları ve Değerlendirilmesi. Kafkas Üniversitesi Sosyal Bilimler Enstitü 19:119-139

2. Küçük N, Gezer O (2017) Doğal Siyah Obsidyen Cevherleri İçin Yığılma Faktörlerinin Belirlenmesi. Afyon Kocatepe Üniversitesi Fen ve Mühendislik. Bilimleri Dergisi 17(3):872-880

3. Akkurt I, Basyigit C, Mavi B, Akkaş A, Günoğlu K (2011) Yüksek Fırın Cüruflu Betonların Radyasyon Soğurma Karakteristiklerinin Belirlenmesi. e-Journal of New World Sciences Academy 6:1175-1181

4. Berger MJ, Hubbell JH (1987) XCOM Photon Cross Section on a Personal Computer NBSIR. 87. NIST, pp. 3597

5. Gerward L, Guilbert N, Jensen KB, Levring H (2001) X-ray absorption in matter. Reengineering Xcom Radiat Phys Chem 60:23-24

6. Awasarmol VV, Gaikwad DK, Raut SD, Pawa PP (2017a) Photon interaction study of organic nonlinear optical materials in the energy range 122-1330 keV. Radiat Phys Chem 130:343-350

7. Awasarmol VV, Gaikwad DK, Raut SD, Pawar PP (2017b) Gamma ray interaction studies of organic nonlinear optical materials in the energy range 122 keV-1330 keV Results Phys. http://dx.doi.org/10.1016/j.rinp.2016.12.017

8. Bhosale RR, Gaikwad DK, Pawar PP, Rode MN (2016a) Effects of gamma irradiation on some chemicals using an Nal (TI) detector. Radiat Eff Defects Solids 171:398-407. http://dx.doi.org/10.1080/10420150.2016.1194418

9. Bhosale RR, Gaikwad DK, Pawar PP, Rode MN (2016b) Interaction studies and gamma-ray properties of some low-Zmaterials Nucl. Technol Radiat Prot 31:135-141. http://dx.doi.org/10.2298/NTRP1602135B

10. Gaikwad DK, Pawar PP, Selvam TP (2016) Measurement of attenuation cross-sections of some fatty acids in the energy range 1221330 keV Pramana-J. Phys. 87, 12. http://dx.doi.org/10.1007/s12043-016-1213-y.

11. Pawar PP, Bichile GK (2013) Studieson mass attenuation coefficient, Zeff andelectron density of some amino acids in the energy range 0.122-1.330 MeV Radiat. Phys. Chem. 92: 22-27. https://doi.org/10.1016/j.radphyschem.2013.07.004

12. Un A, Sahin Y (2011) Determination of mass attenuation coefficients, effective atomic and electron numbers, mean free paths and kermas for PbO, barite and some boron ores Nucl. Instrum. Methods B. 269:1506-1511. https://doi.org/10.1016/j.nimb.2011.04.011

13. Akkurt I, Altindag R, Gunoglu K, Sarıkaya H (2012) Photon attenuation coefficients of concrete including marble aggregates. Annals of Nuclear Energy, 43:56-60. https://doi.org/10.1016/j.anucene.2011.12.031

14. Akkurt I, Akyıldıım H, Karipcin F, Mavi B (2012) Chemical corrosion on gamma-ray attenuation properties of barite concrete. Journal of Saudi Chemical Society 16(2):199-202. https://doi.org/10.1016/j.jscs.2011.01.003

15. Medhat ME (2009) Gamma-ray attenuation coefficients of some building materials available in Egypt. Ann Nucl Energy 36(6):849852. https://doi.org/10.1016/j.anucene.2009.02.006

16. Obaid SS, Sayyed MI, Gaikwad DK, Pawar PP (2018) Attenuation coefficients and exposure buildup factor of some rocks for gamma ray shielding applications. Radiation Physics and Chemistry, 148:86-94. https://doi.org/10.1016/j.radphyschem.2018.02.026

17. Obaid SS, Gaikwad DK, Pawar PP (2018) Determination of gamma ray shielding parameters of rocks and concrete. Radiation Physics and Chemistry 144:356-360. https://doi.org/10.1016/j.radphyschem.2017.09.022

18. Nimet ZA.I M, Hatıpoglu D (2018) Experimental Investigation of Gamma Radiation Attenuation Coefficients for Kırklareli Marble. Süleyman Demirel Üniversitesi Fen Bilimleri Enstitüsü Dergisi 22(1):141-147. DOI:10.19113/sdufbed.22241

19. Mavi B, Oner F, Akkurt I (2015) Determination of Gamma-ray Attenuation Coefficients at Different Energies in Amasya Marbles. Acta Physica Polonica A 128(2B). DOI 10.12693/APhysPolA.128.B-395

20. Ozyurt O, Altinsoy N, Karaaslan Şi, Bora A, Buyuk B, Erk I (2018) Calculation of gamma ray attenuation coefficients of some granite samples using a Monte Carlo simulation code. Radiation Physics and Chemistry 144: 271-275.

https://doi.org/10.1016/j.radphyschem.2017.08.024

21. Cengız GB, Caglar I, Bılır G (2019) Optical Properties and Natural Radioactivity Levels of Turkish Natural Glass Obsidian. The Eurasia Proceedings of Science Technology Engineering and Mathematics. 6(6): 138-141

22. Chiozzi P, De Felice P, Fazio A, Pasquale V, Verdoya M (2000) Laboratory application of Nal (TI) Y-ray spectrometry to studies of natural radioactivity in geophysics. Applied Radiation and isotopes 53(1-2):127-132. https://doi.org/10.1016/S09698043(00)00123-8

23. Yeğingil Z, Boztuğ D, Er M, Oddone M, Bigazzi G (2002) Timing of neotectonic fracturing by fission track dating of obsidian in-filling faults in the Ikizdere-Rize area NE Black Sea region, Turkey. Terra Nova 14(3):169-174. https://doi.org/10.1046/j.13653121.2002.00407.x

Page $9 / 11$ 
24. Ercan T, Yegingil Z, Bigazzi G (2016) Obsidian definition and characteristics, distribution and geochemical characteristics of those of the central Anatolian obsidian in Anatolia. Journal Geomorphol, 17(1989) 71-83

25. Ustabaş I, Kaya A (2018) Comparing the pozzolanic activity properties of obsidian to those of fly ash and blast furnace slag. Constr Build Mater 164:297-307

26. Arslan M, Tuysuz N, Korkmaz S, Kurt H (1997) Geochemistry and petrogenesis of the eastern Pontide volcanic rocks, Northeast Turkey. Chem Erde 57:157-187

27. Özsayar T, Pelin S, Gedikoglu A (1981) Cretaceous in the eastern Pontides, Karadeniz Technical University. Journal of Earth Sciences $1: 65-74$

28. Eyuboglu Y (2006) Description and Geotectonic Important of the Alaskan-Type Ma.c-Ultrama.c Rocks in the Eastern Pontide Magmatic Arc (NE Turkey), PhD Thesis, Karadeniz Technical University, Trabzon, Turkey

29. UNSCEAR (2000) "United Nations Scientific Committee on the Effect of Atomic Radiation to the General Assembly", Sources. Effects and Risk of lonizing Radiation, United Nations, New York

30. Baltas H (2020) Evaluation of gamma attenuation parameters and kerma coefficients of YBaCuO and BiPbSrCaCuO superconductors using EGS4 code. Radiation Physics and Chemistry, 166:108517. https://doi.org/10.1016/j.radphyschem.2019.108517

\section{Figures}
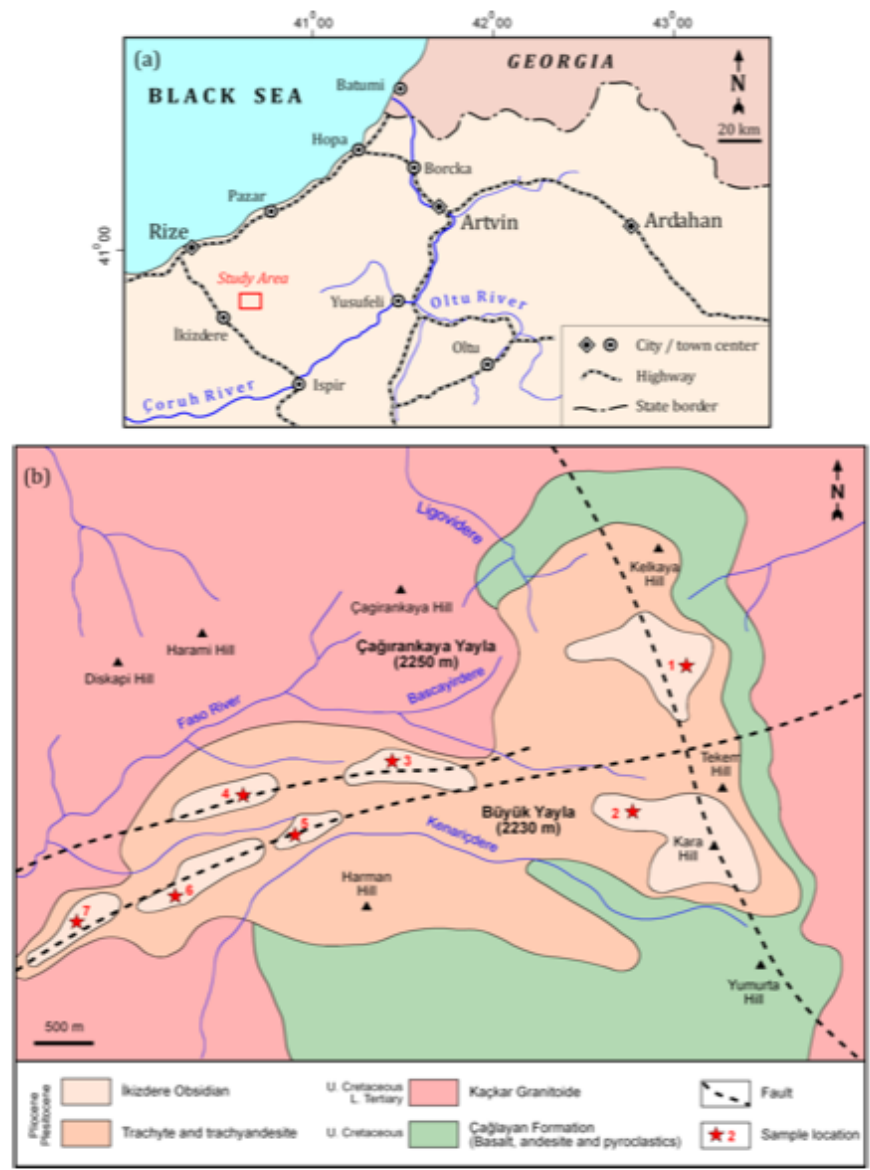

\section{Figure 1}

Geological map of the Ikizdere obsidians. 


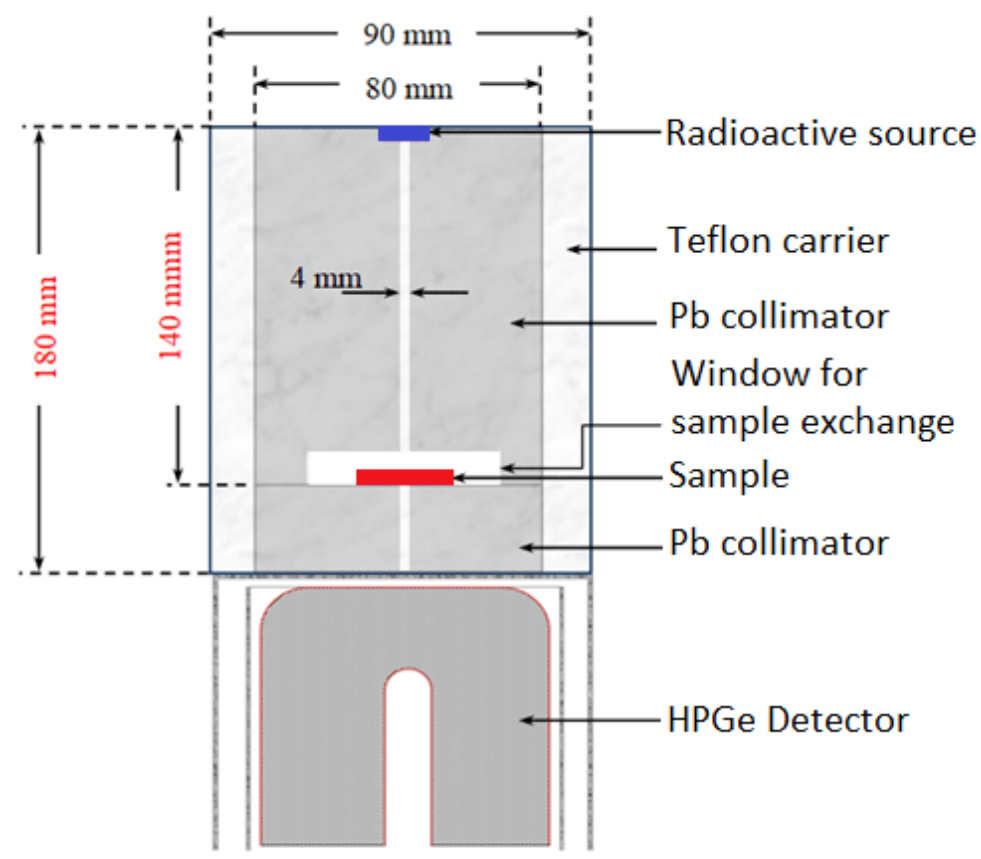

\section{Figure 2}

The used system for gamma ray attenuation measurements 